\title{
Logit Model Approach to the Soekarno-Hatta Malang Bridge Traffic Jam
}

\author{
Alamin Abualgasem ${ }^{1}$, Dr. Sobri Abusini MT ${ }^{2}$ \\ Dr. Abdul Rouf Alghofari, M. SC ${ }^{3}$
}

\begin{abstract}
This paper is intended to explore the application of the logit model in the Soekarno-Hatta Malang bridge traffic jam. Logit model is a model which uses regression technique to estimate the probability that an event occurs or not. The data which is used in this paper is the vehicles data. The vehicles are classified by heavy vehicles (trucks, buses, etc), light vehicles (sedan, pick-up, etc), motorcycles, and unmotorcycles. The result of this research is $66.8 \%$ of motor vehicle will cause traffic jam and $66.9 \%$ of unmotor vehicle will cause traffic jam.
\end{abstract}

Keywords: - logit model, traffic jam, congestion

\section{Introduction}

Congestion is a condition on road networks that occurs as use increases. Congestion is characterized by slower speeds, longer trip times, and increased vehicular queueing. When vehicles are fully stopped for periods of time, this is known as a traffic jam.

Congestion occurs when a volume of traffic generates demand for space greater than the available road capacity. There are a number of specific circumstances which cause congestion; most of them reduce the capacity of a road at a given point or over a certain length, or increase the number of vehicles required for a given volume of people or goods.

Traffic jam is the main problem in the city. Thing that makes traffic jam so big and complex is the unequal increase rate of street width and the increasing of vehicles significantly on the private vehicles.

\section{Objective}

This paper intends to apply logit model to estimate the probability that Soekarno-Hatta Malang bridge traffic jam occurs or not by predicting a binary dependent outcome from a set of independent variables. The independent variables are heavy vehicles (trucks, buses, etc), light vehicles (sedan, pick-up, etc), motorcycles, and unmotorcycles.

\section{Problem Formulation}

Based on the objective, the problem formulation is stated as follows: how to apply the logit model to Soekarno-Hatta Malang bridge traffic jam problem?

\section{Problem Limitation}

1. The application of the logit model is in the Soekarno-Hatta Malang bridge traffic jam problem.

2. The data used in this paper is the number of vehicles which came from Mayjen MT Haryono street, made uturns at Soekarno-Hatta street, and headed to Mayjen DI Panjaitan.

3. The vehicles are classified by heavy vehicles (trucks, buses, etc), light vehicles (sedan, pick-up, etc), motorcycles, and unmotorcycles.

4. The data was taken from 6.00 to 16.00 .

\section{Importance of the Study}

This paper is expected to be the comprehensive approach to make the mathematical model about traffic jam at Soekarno-Hatta street. The result of this study is expected to be used by decision maker to solve the traffic jam problem at Soekarno-Hatta street.

\section{Logit Model}

The logit model was introduced by Joseph Berkson in 1944, who coined the term. Logit model is a model which uses regression technique for the analysis. This model estimates the probability that an event occurs or not by predicting a binary dependent outcome from a set of independent variables. Logit model can also be called logistic model. They are one and same thing. 
First of all we would like to have the probabilities $\boldsymbol{p}$ depend on a vector of observed covariates $\boldsymbol{X}=\left[\begin{array}{l}\mathbf{1} \\ \boldsymbol{x}\end{array}\right]$. The simplest idea would be to let $\boldsymbol{p}$ be a linear function of the covariates, say $\boldsymbol{p}=\boldsymbol{X}^{\boldsymbol{T}} \boldsymbol{B}$, where $\boldsymbol{B}=\left[\begin{array}{l}\boldsymbol{b}_{\mathbf{0}} \\ \boldsymbol{b}_{\mathbf{1}}\end{array}\right]$ is a vector of regression coefficients.

One problem with this model is that the probability on the left-hand-side has to be between zero and one, but the linear predictor on the right-hand-side can take any real value, so there is no guarantee that the predicted values will be in the correct range unless complex restrictions are imposed on the coefficients.

A simple solution to this problem is to transform the probability to remove the range restrictions, and model the transformation as a linear function of the covariates. We do this in two steps.

First, we move from the probability $\boldsymbol{p}$ to the odds. Logit model work with odds rather than proportions. The odds are simply the ratio of the proportions for the two possible outcomes. If $\boldsymbol{p}$ is the proportion for one outcome, then $\mathbf{1}-\boldsymbol{p}$ is the proportion for the second outcome.

odd $s=\frac{p}{1-p}$

Second, we take logarithms, calculating the logit or log-odds and the general form of the simple logit model is $\log \left(\frac{p}{1-p}\right)=b_{0}+b_{1} x$

where $p$ is the binomial proportion, $x$ is the independent variable, $b_{0}$ and $b_{1}$ are the parameters of the logit model.

\section{Data}

The image below shows the trip from Mayjen MT Haryono street to Mayjen DI Panjaitan street.

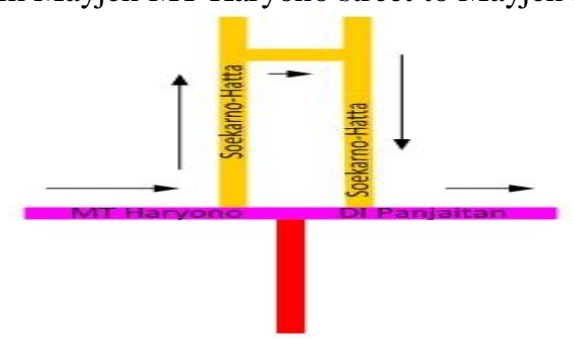

Image 1 The Trip from Mayjen MT Haryono street to Mayjen DI Panjaitan street

Soekarno-Hatta bridge is the bridge which is located in Soekarno-Hatta street Malang. This street has many branches of road where vehicles can make u-turns. A u-turn is a turn made by a vehicle in the shape of a $U$, resulting in a reversal of direction. Many vehicles make u-turns in the rush hour. The vehicles which make uturns are the vehicles which pass Mayjen MT Haryono street, make u-turns at Soekarno-Hatta street, and head to Mayjen DI Panjaitan street. These vehicles often make a traffic jam in the rush hour. We identify that rush hour is from 6.00 to 16.00 . So the data taken below is vehicles data from 6.00 to 16.00 . The vehicles are classified by heavy vehicles (trucks, buses, etc), light vehicles (sedan, pick-up, etc), motorcycles, and unmotorcycles. HV stands for heavy vehicles, LV stands for light vehicles, MC stands for motorcycles, and UM stands for unmotorcycles.

Table 1 The Number of Heavy Vehicles from 6.00 to 16.00

\begin{tabular}{|l|r|r|r|r|r|}
\hline & \multicolumn{5}{|c|}{ HV } \\
\hline Hour & $6-7$ & $7-8$ & $8-9$ & $9-10$ & $10-11$ \\
\hline $\begin{array}{l}\text { No traffic } \\
\text { jam }\end{array}$ & 1101 & 1290 & 1140 & 1228 & 1195 \\
\hline Traffic jam & 1821 & 1711 & 1810 & 1766 & 1859 \\
\hline Hour & $\begin{array}{r}11- \\
12\end{array}$ & $\begin{array}{r}12- \\
13\end{array}$ & $\begin{array}{r}13- \\
14\end{array}$ & $\begin{array}{r}14- \\
15\end{array}$ & $15-16$ \\
\hline $\begin{array}{l}\text { No traffic } \\
\text { jam }\end{array}$ & 1175 & 1186 & 1255 & 1172 & 1163 \\
\hline Traffic jam & 1895 & 1767 & 1791 & 1871 & 1864 \\
\hline
\end{tabular}

Table 2 The Number of Light Vehicles from 6.00 to 16.00

\begin{tabular}{|l|r|r|r|r|r|}
\hline & \multicolumn{5}{|c|}{ LV } \\
\hline Hour & $6-7$ & $7-8$ & $8-9$ & $9-10$ & $10-11$ \\
\hline No traffic jam & 1118 & 1151 & 1170 & 1268 & 1127 \\
\hline Traffic jam & 2472 & 2358 & 2446 & 2308 & 2427 \\
\hline
\end{tabular}


Logit Model Approach to the Soekarno-Hatta Malang Bridge Traffic Jam

\begin{tabular}{|l|r|r|r|r|r|}
\hline Hour & $11-12$ & $12-13$ & $13-14$ & $14-15$ & $15-16$ \\
\hline No traffic jam & 1159 & 1121 & 1294 & 1204 & 1119 \\
\hline Traffic jam & 2320 & 2370 & 2442 & 2487 & 2408 \\
\hline
\end{tabular}

Table 3 The Number of Motorcycles from 6.00 to 16.00

\begin{tabular}{|l|r|r|r|r|r|}
\hline & \multicolumn{5}{|c|}{ MC } \\
\hline Hour & $6-7$ & $7-8$ & $8-9$ & $9-10$ & $10-11$ \\
\hline No traffic jam & 1774 & 1894 & 1878 & 1844 & 1882 \\
\hline Traffic jam & 4249 & 4286 & 4255 & 4173 & 4167 \\
\hline Hour & $11-12$ & $12-13$ & $13-14$ & $14-15$ & $15-16$ \\
\hline No traffic jam & 1785 & 1770 & 1728 & 1791 & 1861 \\
\hline Traffic jam & 4208 & 4229 & 4196 & 4224 & 4101 \\
\hline
\end{tabular}

Table 4 The Number of Unmotorcycles from 6.00 to 16.00

\begin{tabular}{|l|r|r|r|r|r|}
\hline & UM & & & & \\
\hline Hour & $6-7$ & $7-8$ & $8-9$ & $9-10$ & $10-11$ \\
\hline No traffic jam & 583 & 610 & 566 & 563 & 614 \\
\hline Traffic jam & 1283 & 1298 & 1292 & 1147 & 1146 \\
\hline Hour & $11-12$ & $12-13$ & $13-14$ & $14-15$ & $15-16$ \\
\hline No traffic jam & 561 & 592 & 639 & 650 & 602 \\
\hline Traffic jam & 1268 & 1125 & 1214 & 1173 & 1120 \\
\hline
\end{tabular}

VIII. Computation

Table 5 below shows the summary of table 1 to table 4 .

\begin{tabular}{|l|r|r|r|r|r|}
\hline & HV & LV & MC & UM & Total \\
\hline $\begin{array}{l}\text { No traffic } \\
\text { jam }\end{array}$ & 11905 & 11731 & 18207 & 5980 & 47823 \\
\hline Traffic jam & 18155 & 24038 & 42088 & 12066 & 96347 \\
\hline Total & 30060 & 35769 & 60295 & 18046 & 144170 \\
\hline
\end{tabular}

Table 5 The Number of Vehicles from 6.00 to 16.00

Table 6 below shows the number of vehicles in one second, so all of the data are divided by 3600 .

\begin{tabular}{|l|r|r|r|r|r|}
\hline & HV & LV & MC & UM & Total \\
\hline $\begin{array}{l}\text { No traffic } \\
\text { jam }\end{array}$ & 3.307 & 3.259 & 5.058 & 1.661 & 13.284 \\
\hline Traffic jam & 5.043 & 6.677 & 11.691 & 3.352 & 26.763 \\
\hline Total & 8.350 & 9.936 & 16.749 & 5.013 & 40.047 \\
\hline
\end{tabular}

Table 6 The Number of Vehicles in 1 Second

Table 7 below shows the classification of the vehicles. $\mathrm{M}$ for motor vehicles and $\mathrm{U}$ for unmotorcycle.

\begin{tabular}{|l|r|r|r|}
\hline & $\mathrm{M}$ & $\mathrm{U}$ & Total \\
\hline $\begin{array}{l}\text { No traffic } \\
\text { jam }\end{array}$ & 11.623 & 1.661 & 13.284 \\
\hline Traffic jam & 23.411 & 3.352 & 26.763 \\
\hline Total & 35.034 & 5.013 & 40.047 \\
\hline
\end{tabular}

Table 7 The Classification

Table 7 is a cross tabulation of two binary variables for a sample of vehicles. We can see that the majority of the sample of vehicles with motor cause traffic jam.

A useful way of using the information in cross tabulationsis to calculate odds. 


\begin{tabular}{|l|r|r|r|}
\hline \multirow{2}{*}{} & \multicolumn{3}{|c|}{ Odds } \\
\cline { 2 - 4 } & $\mathrm{M}$ & $\mathrm{U}$ & Total \\
\hline $\begin{array}{l}\text { No traffic } \\
\text { jam }\end{array}$ & 0.496 & 0.496 & 0.992 \\
\hline Traffic jam & 2.014 & 2.018 & 4.032 \\
\hline Total & 2.511 & 2.513 & 5.024 \\
\hline
\end{tabular}

Table 8 The Odds

Then, we take logarithms, calculating the logit or log-odds.

\begin{tabular}{|l|r|r|}
\hline \multirow{2}{*}{} & \multicolumn{2}{|c|}{$\log$ Odds } \\
\cline { 2 - 3 } & $\mathrm{M}$ & $\mathrm{U}$ \\
\hline No traffic jam & -0.700 & -0.702 \\
\hline Traffic jam & 0.700 & 0.702 \\
\hline
\end{tabular}

Table 9 The log Odds

We can interpret as the log odds of a motor vehicle seen as causing traffic jam is 0.700 and the log odds of an unmotor vehicle seen as causing traffic jam is 0.702 .

The logit model is $\log \mathrm{J}=0.700+0.002 \mathrm{~V}$.

The model above is the Soekarno-Hatta Malang bridge traffic jam prediction. The predicted traffic jam can be interpreted as the predicted probability of traffic jam for the given vehicle. Therefore the parameter 0.700 gives the log odds of a motor vehicle seen as causing traffic jam and 0.002 shows how these log odds differ for unmotorcycle.

\begin{tabular}{|l|r|}
\hline & Odds \\
\hline $\mathrm{M}$ & 2.014 \\
\hline $\mathrm{U}$ & 2.018 \\
\hline
\end{tabular}

Table 10 The Odds for Traffic Jam

We can now use this model to predict the odds that a vehicle will cause traffic jam. If a vehicle is a motor vehicle (heavy vehicle, light vehicle, or motorcycle), then the odds is 2.014 . That is, a motor is likely 2.014 to cause traffic jam. If a vehicle is an unmotor vehicle, then the odds is 2.018 . That is, an unmotor is 2.018 more likely to cause traffic jam.

\begin{tabular}{|l|r|}
\hline & Probabilities \\
\hline $\mathrm{M}$ & 0.668 \\
\hline $\mathrm{U}$ & 0.669 \\
\hline
\end{tabular}

Table 10 The Probabilities

We can convert odds to probabilities. That is, the model predicts $66.8 \%$ of motor vehicle will cause traffic jam and the model predicts $66.9 \%$ of unmotor vehicle will cause traffic jam.

\section{Conclusion}

1. The logit model for the Soekarno-Hatta Malang bridge traffic jam prediction is $\log \mathrm{J}=0.700+0.002 \mathrm{~V}$.

2. The model predicts $66.8 \%$ of motor vehicle will cause traffic jam and the model predicts $66.9 \%$ of unmotor vehicle will cause traffic jam.

\section{Suggestion}

We hope that the result of this research can be used as recommendation to the authority to close the branch of Soekarno-Hatta street. If the branch of Soekarno-Hatta street is closed the vehicles can't make u-turns and the traffic jam will reduce.

\section{References}

[1] Hosmer, D.W. dan S. Lemeshow. (2000). Applied Logistic Regression, 2nd edition. John Wiley and Sons.

[2] Agresti, A. (1996) Introduction to Categorical Data Analysis. John Wiley.

[3] J. S. Cramer (2003). "The Origins and Development of the Logit Model". Cambridge UP. 